\title{
TANAM LINGKAR BERJAJAR UNTUK MENINGKATKAN POPULASI DAN PRODUKSI PADA TANAMAN JAGUNG MANIS (Zea mays - Saccharata)
}

\author{
Cropping Pattern of Circle-lined Row to Increase Population and Production in Sweet \\ Corn (Zea mays - Saccharata)
}

\author{
Use Etica dan Mahmudah Hamawi \\ Universitas Darussalam Gontor Ponorogo Jawa Timur \\ E-mail : mahmudahhamawi@unida.gontor.ac.id
}

\begin{abstract}
ABSTRAK
Produksi jagung manis dapat ditingkatkan melalui perbaikan genetik dan pengaturan ruang (tumbuh melalui pengaturan populasi tanaman dan ketersediaan unsurhara dan air yang cukup). Tujuan dari penelitian adalah untuk mengetahui pengaruh tanam lingkar berjajar terhadap populasi dan produksi tanaman jagung manis. Penelitian dilaksanakan pada bulan Juli - Oktober 2017 di Ponorogo, Jawa Timur dengan ketinggian $140 \mathrm{~m}$ dpl dan jenis tanah adalah grumosol. Penelitian ini menggunakan Rancangan Acak Kelompok (RAK) yang terdiri dari empat perlakuan dengan enam kali ulangan. Faktor yang diteliti adalah metode tanam, meliputi : tanam tunggal dengan jarak tanam 20x60 cm; tanam lingkar berjajar dengan jarak tanam $50 \times 70 \mathrm{~cm}$; tanam lingkar berjajar dengan jarak tanam 60x80 $\mathrm{cm}$; tanam lingkar berjajar dengan jarak tanam 70x80 $\mathrm{cm}$. Hasil penelitian menunjukkan bahwa : 1). Perlakuan tanam lingkar berjajar meningkatkan populasi tanaman jagung manis sebesar 239 - $274 \%$ dari tanam tunggal. 2). Tanam Lingkar berjajar dengan jarak tanam $70 \times 80 \mathrm{~cm}$ dengan jumlah populasi 75.382 per Ha menghasilkan berat tongkol segar sebesar 26,06 ton/Ha.
\end{abstract}

Kata kunci: jagung manis, tanam lingkar berjajar, populasi, berat tongkol segar

\begin{abstract}
Sweet corn production can be improved through genetic improvements, plant growing space arrangements with plants populations arranggements and the availability of sufficient nutrients and water.The aim of this research is to analyze the effect of circle-lined row cropping pattern to the population and production of sweet corn. The reseach was conducted in July to October 2017 in Ponorogo, Jawa Timur, with a height of $140 \mathrm{~m}$ above sea level and soil grumosol type. This research used Randomized Block Design (RBD), consisted of 4 cropping pattern treatmentsand 6 replications. The cropping pattern treatments was cropping pattern of single-lined row with scaping $20 \times 60 \mathrm{~cm}$, cropping pattern of circlelined row with spacing $50 \times 70 \mathrm{~cm}$, cropping pattern of circle-lined row with spacing 60x80 cm, cropping pattern of circle-lined row with spacing 70x80 $\mathrm{cm}$. The result showed that : 1). Cropping pattern of circle-lined row was increased sweet corn population by 239 - $274 \%$ from cropping pattern of single-lined row, 2). Cropping pattern of circle-lined row with scpacing 70x80 cm with 75.382 per Ha population produces fresh cob weight of 26,06 ton/Ha.
\end{abstract}


Keywords : sweet corn, circle-lined row cropping pattern, population, fresh cob weight

\section{PENDAHULUAN}

Jagung manis sebagai salah satu produk hortikultura yang bernilai ekonomis. Berbagai makanan olahan berbasis jagung manis sudah banyak dikembangkan. Jagung manis diolah menjadi susu jagung, bakwan jagung, jenang jagung, jagung beku, jagung bakar atau rebus. Pada daerah wisata penjualan jagung manis sebagai jagung bakar sangat digemari oleh wisatawan.

Biji jagung manis memiliki cita rasa yang enak dan bergizi. Jagung manis mengadung karbohidrat, protein, vitamin yang tinggi, dan rendah lemak. Jagung manis memiliki kadar gula, vitamin $\mathrm{A}$ dan $\mathrm{C}$ yang lebih tinggi dibandingkan jagung biasa, serta memiliki kadar lemak yang rendah dibanding jagung biasa (Iskandar 2007). Masyarakat suka mengkonsumsi jagung manis sehingga permintaan pasar akan jagung manis selalu ada sepanjang tahun.

Jagung manis memiliki usia panen berkisar 70 - 85 hari setelah tanam, sehingga petani sangat antusias dalam mebudidayakannya. Potensi hasil produksi jagung manis hibrida (Bonanza 2 F1) mencapai 15 - 20 ton per ha tongkol segar, dengan bobot per tongkol jagung 300 - 400 g (Anonymous, 2017). Hasil produksi jagung manis milik petani seringkali tidak mencapai potensi hasil produksinya. Produksi tanaman jagung dipengaruhi beberapa faktor diantaranya populasi tanaman jagung.Jumlah populasi tanaman jagung dapat mempengaruhi hasil produksi jagung setiap hektarnya.

Metode tanam lingkar sejajar merupakan salah satu metode tanam jagung yang mampu meningkatkan populasi tanaman jagung. Metode tanam cara lingkar benjajar jarak tanam 100x50x50 meningkatkan populasi tanaman jagung sebesar 164.413 tanaman/ha (Etica dan Hamawi, 2016). Kepadatan populasi tanaman jagung dapat ditingkatkan sampai mencapai daya dukung lingkungannya. Keterbatasan ruang tumbuh pada akhirnya akan menjadi pembatas untuk mendapatkan produksi yang optimal. Hubungan kerapatan tanaman jagung dengan hasil panen biji akan membentuk respon kurva parabola. Peningkatan kerapatan akan meningkatkan hasil panen sampai pada titik kerapatan tertentu. Puncak parabola akan mendatar dengan penurunan hasil panen pada kedua sisi 
dari suatu nilai optimum (Gardner et.al, 1991).Tujuan dari penelitian adalah untuk mengetahui pengaruh tanam lingkar berjajar terhadap populasi dan produksi tanaman jagung manis.

\section{METODE PENELITIAN}

Penelitian dilaksanakan di Ponorogo, Jawa Timur dengan ketinggian 140 m dpl dan jenis tanah adalah grumosol bertekstur liat. Penelitian dilaksanakan pada bulan Juli - Oktober 2017. Penelitian ini menggunakan Rancangan Acak Kelompok (RAK) yang terdiri dari empat perlakuan dengan enam kali ulangan. Faktor yang diteliti adalah metode tanam, meliputi : tanam tunggal dengan jarak tanam 20x60 cm; tanam lingkar berjajar dengan jarak tanam 50x70 cm; tanam lingkar berjajar dengan jarak tanam 60x80 cm; tanam lingkar berjajar dengan jarak tanam 70x80 cm (Gambar 1.). Parameter pengamatan meliputi : tinggi tanaman, lingkar batang, berat kering tanaman, jumlah populasi, bobot tongkol jagung, diameter jagung tanpa kelobot, panjang tongkol berbiji dan indeks panen.

Pelaksanaan penelitian ini menggunakan bahan - bahan berupa : benih jagung manis hibrida. Sarana produksi yang digunakan berupa pupuk organik (petroganik), Urea, ZA, NPK Phonska dan pestisida (insektisida dan fungisida), serta herbisida. Alat yang digunakan dalam penelitian ini antara lain : meteran penggaris, rol meter, jangka sorong, cangkul, tugal, alat tanam lingkar berjajar, sabit, hand sprayer, papan label, alat tulis, timbangan, oven.

Tahapan penyiapan lahan antara lain : pembersihan lahan dari gulma dengan disemprot herbisida, pembuatan petak perlakuan dan saluran air irigasi dan drainase. Lubang tanam dibuat dengan tugal sedalam 3-5 cm, tiap lubang diisi satu butir benih. Jarak tanam disesuaikan dengan perlakuan dalam penelitian, yaitu :

Pemupukan dilakukan sebanyak tiga kali : Pemupukan pertama yaitu pemberian pupuk urea dan phonska pada umur 2 minggu setelah tanam (MST) dosis $75 \mathrm{~g} /$ tanaman dengan perbandingan $1: 2$. Pupuk ke dua yaitu pemberian ZA pada umur 6 MST dosis $25 \mathrm{~g} /$ tanaman. Pupuk ke tiga yaitu pemberian urea pada umur $8 \mathrm{MST}$ dosis $25 \mathrm{~g} /$ tanaman. Pupuk organik diberikan waktu tanam sebagai penimbun benih jagung manis. Pengairan disesuaikan dengan cuaca dan 
kelembaban tanah. Penyemprotan insektisida dan fungisisda disesuaikan dengan keadaan serangan hama penyakit tanaman jagung.

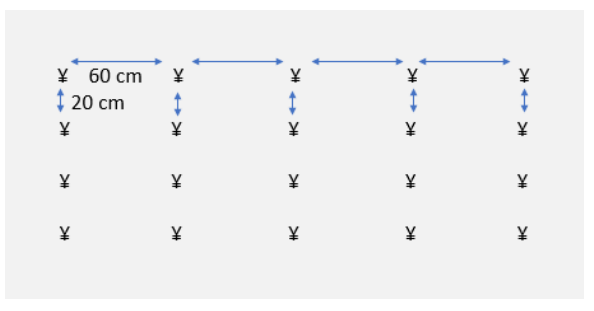

a.

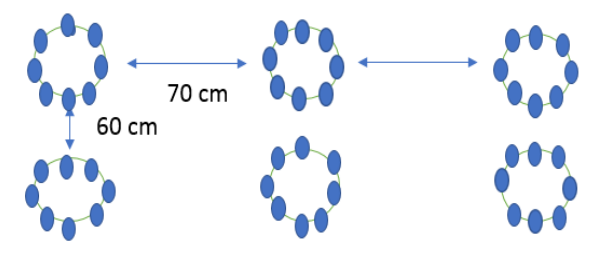

c.

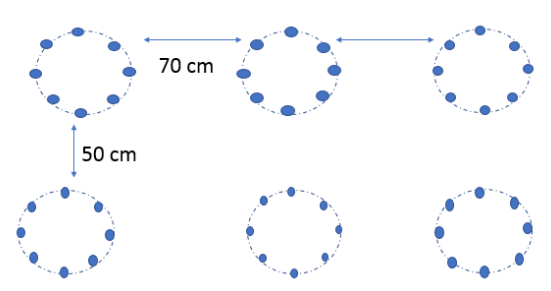

b.

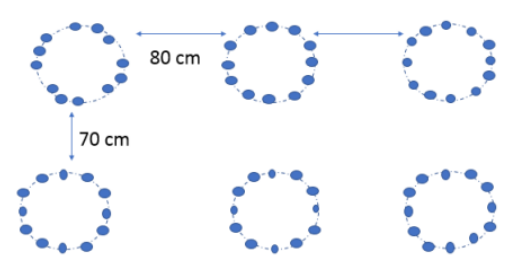

d.

Gambar 1. Metode tanam a. tunggal dengan jarak tanam 20x60 cm; b.lingkar berjajar dengan jarak tanam 50x70 cm; c. lingkar berjajar dengan jarak tanam $60 \times 70 \mathrm{~cm}$; d. lingkar berjajar dengan jarak tanam 70x80 cm.

\section{HASIL DAN PEMBAHASAN}

Tabel 1. Hasil Analisis Ragam Variabel Pengamatan Tanam Lingkar Berjajar

\begin{tabular}{|c|c|c|c|c|c|c|}
\hline \multirow{2}{*}{ No. } & \multirow{2}{*}{ Variabel Pengamatan } & \multicolumn{4}{|c|}{ Umur Pengamatan (HST) } & \multirow{2}{*}{$\begin{array}{c}\text { Panen } \\
(75 \text { HST })\end{array}$} \\
\hline & & 20 & 30 & 40 & 50 & \\
\hline 1. & Jumlah Populasi Tanaman & - & $* *$ & - & - & - \\
\hline 2. & Tinggi Tanaman & ns & ns & ns & ns & - \\
\hline 3. & Lingkar Batang & ns & ns & $* *$ & $* *$ & - \\
\hline 4. & Berat kering & ns & ns & ns & $* *$ & - \\
\hline 5. & Berat Tongkol Segar (per ha) & - & - & - & - & $* *$ \\
\hline 6. & $\begin{array}{l}\text { Berat Rata - Rata Tongkol } \\
\text { perbiji }\end{array}$ & - & - & - & - & ns \\
\hline 7. & $\begin{array}{l}\text { Diameter Tongkol tanpa } \\
\text { Klobot/kulit }\end{array}$ & - & - & - & - & ns \\
\hline 8. & Panjang Tongkol Berbiji & - & - & - & - & ns \\
\hline 9. & Indeks Panen & - & - & - & - & ns \\
\hline
\end{tabular}

Hasil analisis ragam pada tabel 1. menunjukkan bahwa tanam lingkar berjajar berpengaruh sangat nyata terhadap populasi tanaman pada umur 30 hari 
setelah tanam (HST), lingkar batang pada umur 40 dan 50 HST, berat kering pada umur 50 HST dan hasil panen (berat tongkol segar) pada umur 75 HST. Tanam lingkar berjajar tidak berpengaruh nyata terhadap tinggi tanaman, bobot tongkol per biji, panjang tongkol berbiji, diameter tongkol tanpa klobot/kulit, dan indeks panen.

\section{Jumlah Populasi Tanaman}

Hasil analisis ragam menunjukkan bahwa jumlah populasi sangat nyata dipengaruhi oleh tanam lingkar berjajar (tabel 2.).

Tabel 2. Jumlah Populasi Tanaman

\begin{tabular}{lrrrr}
\hline \multirow{2}{*}{ Perlakuan } & \multicolumn{3}{c}{ Jumlah Populasi per Ha } \\
\cline { 2 - 5 } & Umur 20 & Umur 40 \\
& HST & HST \\
\hline Tanam tunggal dengan jarak tanam 20x60 cm & 66767 & a & 42014 & a \\
Tanam lingkar berjajar dengan jarak tanam $50 \times 70 \mathrm{~cm}$ & 182611 & $\mathrm{c}$ & 81458 & $\mathrm{~b}$ \\
Tanam lingkar berjajar dengan jarak tanam $60 \times 80 \mathrm{~cm}$ & 159785 & $\mathrm{~b}$ & 77257 & $\mathrm{~b}$ \\
Tanam lingkar berjajar dengan jarak tanam 70x80 cm & 164350 & $\mathrm{~b}$ & 75382 & $\mathrm{~b}$ \\
\hline Keterangan : Bilangan yang didampingi huruf yang sama pada kolom yang sama tidak \\
berbeda nyata berdasarkan uji LSD pada taraf $\alpha=0,01$
\end{tabular}

\section{Tinggi Tanaman Jagung Manis}

Perlakuan tanam lingkar berjajar tidak berpengaruh terhadap tinggi tanaman jagung manis (tabel 3.)

Tabel 3. Tinggi Tanaman Jagung Manis

\begin{tabular}{lllllllll}
\hline \multirow{2}{*}{ Perlakuan } & \multicolumn{7}{c}{ Umur Pengamatan $(\mathrm{cm})$} \\
\cline { 2 - 8 } & 20 HST & 30 HST & 40 HST & 50 HST \\
\hline $\begin{array}{l}\text { Tanam tunggal dengan jarak } \\
\text { tanam 20x60 cm }\end{array}$ & 28,93 & a & 66,17 & a & 116,23 & a & 188,93 & a \\
$\begin{array}{l}\text { Tanam lingkar berjajar dengan } \\
\text { jarak tanam 50x70 cm }\end{array}$ & 32,53 & a & 74,73 & a & 130,23 & a & 193,77 & a \\
$\begin{array}{l}\text { Tanam lingkar berjajar dengan } \\
\text { jarak tanam 60x80 cm }\end{array}$ & 36,93 & a & 72,30 & a & 131,13 & a & 195,87 & a \\
$\begin{array}{l}\text { Tanam lingkar berjajar dengan } \\
\text { jarak tanam 70x80 cm }\end{array}$ & 31,53 & a & 71,40 & a & 126,33 & a & 190,00 & a \\
\hline $\begin{array}{l}\text { Keterangan : Bilangan yang didampingi huruf yang sama pada kolom yang sama tidak } \\
\text { berbeda nyata berdasarkan uji LSD pada taraf } \alpha=0,01\end{array}$ &
\end{tabular}




\section{Lingkar Batang Tanaman Jagung Manis}

Lingkar batang tanaman jagung manis dipengaruhi oleh perlakuan tanam kingkar berjajar pada umur pengamatan 40 HST dan 50 HST (tabel 4.).

Tabel 4. Lingkar Batang Tanaman Jagung Manis

\begin{tabular}{lccccccccc}
\hline \multirow{2}{*}{ Perlakuan } & \multicolumn{7}{c}{ Umur Pengamatan (cm) (HST) } \\
\cline { 2 - 8 } & 20 HST & 30 HST & 40 HST & 50 HST \\
\hline $\begin{array}{l}\text { Tanam tunggal dengan jarak } \\
\text { tanam 20x60 cm }\end{array}$ & 3,81 & a & 6,50 & a & 8,26 & b & 8,35 & b \\
$\begin{array}{l}\text { Tanam lingkar berjajar dengan } \\
\text { jarak tanam 50x70 cm }\end{array}$ & 4,04 & a & 6,26 & a & 7,22 & a & 7,24 & a \\
$\begin{array}{l}\text { Tanam lingkar berjajar dengan } \\
\text { jarak tanam 60x80 cm }\end{array}$ & 4,04 & a & 6,56 & a & 7,45 & a & 7,45 & a \\
$\begin{array}{l}\text { Tanam lingkar berjajar dengan } \\
\text { jarak tanam 70x80 cm }\end{array}$ & 3,94 & a & 6,42 & a & 7,83 & b & 7,84 & b \\
\hline
\end{tabular}

Keterangan : Bilangan yang didampingi huruf yang sama pada kolom yang sama tidak berbeda nyata berdasarkan uji LSD pada taraf $\alpha=0,01$

\section{Berat Kering Tanaman}

Berat kering tanaman jagung manis dipengaruhi oleh perlakuan tanam lingkar berjajar pada umur pengamatan 50 HST (tabel 5.)

Pada pengamatan umur 50 HST perlakuan tanam tunggal dengan jarak tanam 20x60 cm menghasilkan pertumbuhan sebesar 120,77 g dan berbeda sangat nyata dengan perlakuan lingkar berjajar.

Tabel 5. Berat Kering Tanaman Jagung Manis

\begin{tabular}{|c|c|c|c|c|c|c|c|c|}
\hline \multirow{2}{*}{ Perlakuan } & \multicolumn{8}{|c|}{ Umur Pengamatan (g) } \\
\hline & $20 \mathrm{H}$ & & $30 \mathrm{H}$ & & $40 \mathrm{HS}$ & & $50 \mathrm{HS}$ & \\
\hline $\begin{array}{l}\text { Tanam tunggal dengan jarak tanam } \\
20 \times 60 \mathrm{~cm}\end{array}$ & 2,50 & $\mathrm{a}$ & 8,57 & $\mathrm{a}$ & 12,31 & $\mathrm{a}$ & 120,77 & $\mathrm{c}$ \\
\hline $\begin{array}{l}\text { Tanam lingkar berjajar dengan jarak } \\
\text { tanam } 50 \times 70 \mathrm{~cm}\end{array}$ & 1,80 & $\mathrm{a}$ & 9,51 & $\mathrm{a}$ & 14,18 & $\mathrm{a}$ & 91,04 & $a b$ \\
\hline $\begin{array}{l}\text { Tanam lingkar berjajar dengan jarak } \\
\text { tanam } 60 \times 80 \mathrm{~cm}\end{array}$ & 1,65 & $\mathrm{a}$ & 5,62 & $\mathrm{a}$ & 13,76 & $\mathrm{a}$ & 96,30 & $\mathrm{~b}$ \\
\hline $\begin{array}{l}\text { Tanam lingkar berjajar dengan jarak } \\
\text { tanam } 70 \times 80 \mathrm{~cm}\end{array}$ & 2,54 & $\mathrm{a}$ & 7,02 & $\mathrm{a}$ & 17,31 & $\mathrm{a}$ & 82,00 & $\mathrm{a}$ \\
\hline
\end{tabular}

Keterangan : Bilangan yang didampingi huruf yang sama pada kolom yang sama tidak berbeda nyata berdasarkan uji LSD pada taraf $\alpha=0,01$

\section{Pengamatan Panen}

Pada tabel 6. perlakuan tanam lingkar berjajar mempengaruhi berat tongkol segar per Ha. Perlakuan tanam lingkar berjajar tidak mempengaruhi berat 
rata - rata tongkol per biji, diameter tongkol tanpa klobot, panjang tongkol berbiji dan indeks panen.

Tabel 6. Berat Tongkol Segar per Ha, Berat Rata - Rata Tongkol per biji, Panjang Tongkol Berbiji dan Indeks Panen Jagung Manis

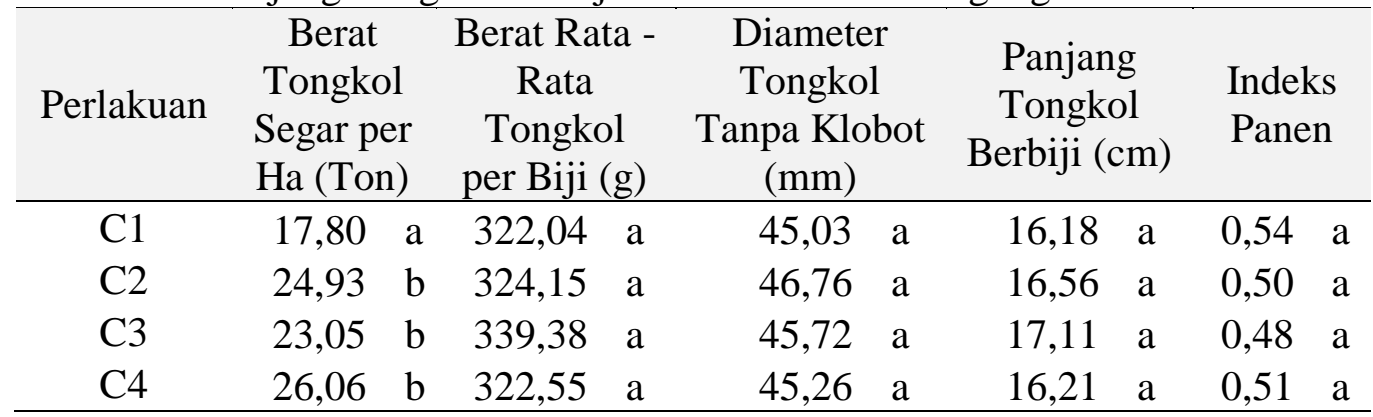

Ket : $\mathrm{C} 1=$ tanam tunggal dengan jarak tanam $20 \times 60 \mathrm{~cm} ; \mathrm{C} 2=$ tanam lingkar berjajar dengan jarak tanam 50x70 cm; $\mathrm{C} 3=$ tanam lingkar berjajar dengan jarak tanam 60x80 cm; $\mathrm{C} 4=$ tanam lingkar berjajar dengan jarak tanam 70x80 cm. Bilangan yang didampingi huruf yang sama pada kolom yang sama tidak berbeda nyata berdasarkan uji LSD pada taraf $\alpha=0,01$

Populasi awal jagung manis dipengaruhi oleh perkecambahan benih jagung manis. Populasi awal jagung manis diamati pada umur 20 HST dengan asumsi bahwa tidak ada lagi benih jagung manis yang masih berkecambah. Jumlah populasi tanaman jagung manis pada perlakuan tanam lingkar berjajar jarak tanam 50x70 cm menghasilkan jumlah populasi 182.611 tanaman padi per Ha dan sangat berbeda nyata dengan populasi pada perlakuan yang lainnya. Perlakuan tanam lingkar berjajar meningkatkan populasi tanaman $239-274 \%$ dari tanam tunggal.

Tanaman jagung manis terserang jamur Peronosclerospora maydis. Usaha pengelolaan serangan jamur dilakukan dengan penyemprotan fungisida pada tanaman jagung manis yang masih sehat dan mencabut tanaman jagung manis yang sudah terserang jamur sangat parah. Serangan jamur mengurangi populasi tanaman jagung manis. Pada umur 40 HST dilakukan pengamatan populasi tanaman jagung manis dengan asumsi pada umur 40 HST tanaman jagung manis yang sehat akan tahan terhadap infeksi jamur Peronosclerospora maydis. Perlakuan tanam lingkar berjajar dengan jarak tanam 50x70 cm tetap memiliki populasi terbanyak yaitu 81.458 tanaman per Ha tetapi tidak berbeda nyata 
dengan tanaman lingkar berjajar jarak tanam 60x80 cm dan jarak tanam 70x80 $\mathrm{cm}$, serta berbeda nyata dengan tanam tunggal dengan jarak tanam 20x60 cm.

Serangan jamur Peronosclerospora maydis menurunkan populasi tanaman jagung manis. Populasi tanam tunggal dengan jarak tanam 20x60 cm tinggal 62,9 $\%$ dari populasi awal. Populasitanam lingkar berjajar dengan jarak tanam 50x70 $\mathrm{cm}$ tinggal 44,6 \% dari populasi awal. Populasitanam lingkar berjajar dengan jarak tanam 60x80 cm tinggal 48,35 \% dari populasi awal. Populasi tanam lingkar berjajar dengan jarak tanam 70x80 cm tinggal 45,87 \% dari populasi awal. Populasi tanaman jagung manis yang tinggi akan meningkatkan serangan jamur Peronosclerospora maydistetapi populasi yang tinggi membantu mempertahankan jumlah tanaman jagung manis setelah terjadi serangan.Serangan jamur Peronosclerospora maydis mengurangi jumlah populasi sebesar 37,1 - 55,4\%.

Tinggi tanaman jagung manis tidak dipengaruhi oleh perlakuan tanam lingkar berjajar. Perlakuan tanam lingkar berjajar masih memberikan ruang untuk tanaman jagung manis dalam memperoleh cahaya matahari. Hasil penelitian Larosa dan Sismanungkalit (2014), menunjukkan bahwa jarak tanam tidak mempengaruhi tinggi tanaman jagung manis. Pada Gambar 2. diketahui bahwa perlakuan tanam tunggal dengan jarak tanam 20x60 cm (C1) memiliki tinggi tanaman yang paling rendah dibandingkan dengan perlakuan lainnya. Populasi tanaman pada perlakuan tanam tunggal dengan jarak tanam 20x60 cm merupakan populasi yang paling sedikit diantara perlakuan lainnya. Tanaman dengan populasi tinggi akan meningkatkan tinggi tanaman akibat dari perebutan sinar matahari.

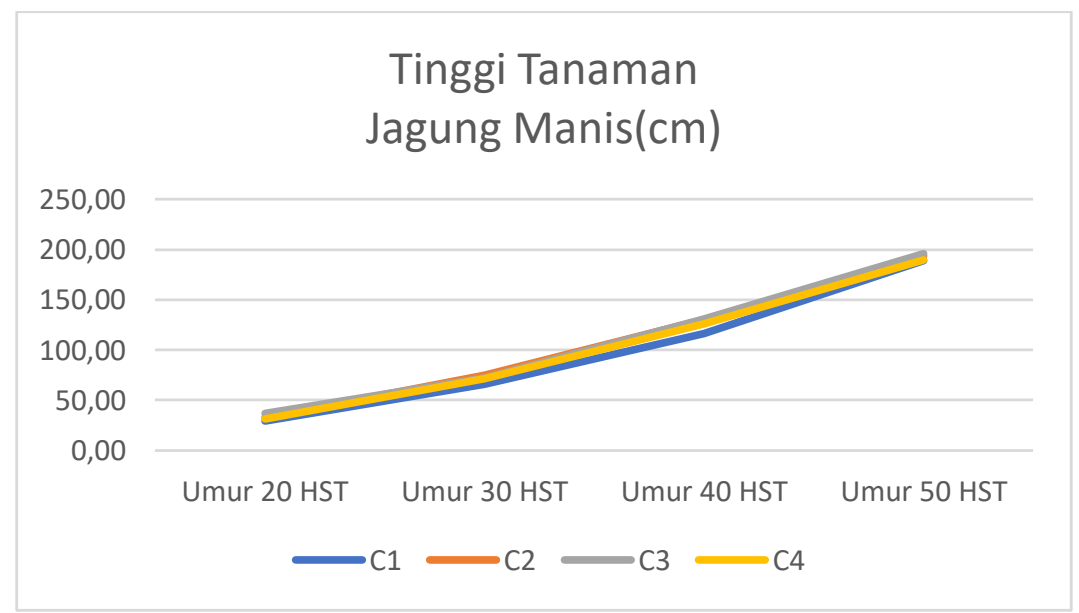

Gambar 2. Tinggi Tanaman Jagung Manis 
Lingkar batang tanaman jagung manis paling besar diperoleh oleh perlakuan tanam tunggal dengan jarak tanam 20x60 $\mathrm{cm}$ pada pemangatan $40 \mathrm{HST}$ dan 50 HST yaitu $8,26 \mathrm{~cm}$ dan $8,35 \mathrm{~cm}$ yang tidak berbeda nyata dengan tanam lingkar berjajar dengan jarak tanam 70x80 cm yaitu 7,83 cm dan 7,84 cm. Pada umur 40 HST perlakuan tanam tunggal dengan jarak tanam 20x60 cm memiliki jumlah populasi tanaman jagung manis yang paling sedikit dengan lingkar batang yang paling besar walaupun tidak berbeda nyata dengan dengan tanam lingkar berjajar dengan jarak tanam 70x80 $\mathrm{cm}$. Populasi tanaman yang tinggi meningkatkan jumlah tanaman yang rebah dan menurunkan diameter batang (Koswara 1986).

Berat kering tanaman sebagai indiktaor pertumbuhan tanaman. Penimbunan berat kering umumnya digubakan sebagai petunjuk yang memberikan ciri pertumbuhan dan laju pertumbuhan tanaman dipengaruhi oleh genetik tanaman dan lingkungan (Gardner dkk., 1991).Tanaman jagung manis mengalami pertumbuhan yang cepat menjelnag umur 50 HST dan tanaman mulai mempersiapkan keluarnya bunga. Berata kering pada umur 50 HST sangat dipengaruhi oleh perlakuan lingkar berjajar. Perlakuan tanama tunggal dengan jarak tanam 20x60 cm pada umur 50 HST menghasilkan berat kering sebesar 120,77 g/tanaman dan berbeda sangat nyata dengan perlakuan tanam lingkar berjajar.

Pada Tabel 2. menunjukan bahwa populasi paling rendah dilimiki oleh perlakuan tanam tungglk dengan jarak tanam 20x60 cm. Populasi mempengaruhi berat kering tanaman (tabel 5.) dan lingkar batang tanaman (tabel 4.). Pengaturan populasi tanaman merupakan pengaturan ruang hidup tanaman sehingga persaingan dalam pengambilan hara, air dan cahaya matahari diantara tanaman dapat ditekan sekecil - kecilnya (Rambitan 2004).

Pengamatan panen menunjukan bahwa perlakuan tanam lingkar berjajar dengan jarak tanam 70x80 cm menghasilkan berat tongkol segar tertinggi yaitu 26,06 ton per Ha yang sangat berbeda nyata dengan perlakuan tanam tunggal dengan jarak tanam 20x60 cm tetapi tidak berbeda nyata dengan perlakuan tanam lingkar berjajar dengan jarak tanam 50x70 cm dan tanam lingkar berjajar dengan jarak tanam 60x80 cm. 
Perlakuan tanam lingkar berjajar tidak berpengaruh nyata terhadap berat tongkol per biji, diameter tongkol tanpa kulit, panjang tongkol berbiji dan indeks panen. Perlakuan tanam lingkar berjajar walaupun meningkatkan jumlah populasi tanaman tetapi tidak berpengaruh nyata terhadap pengamatan berat tongkol perbiji, diameter tongkol tanpa kulit, panjang tongkol berbiji dan indeks panen. Penanaman satu tanaman perlubang tanam dan pemberian pupuk dan air yang cukup bagi pertumbuhan tanaman tetap menghasilkan hasil panen yang tinggi pada populasi yang optimum. Jagung termasuk tanaman $\mathrm{C} 4$ yang efisien dalam fotosintesis karena tidak adanya fotorespirasi (Gardner dkk. 1991). Sehingga pada populasi optimum tanaman jagung tidak berpengaruh terhadap efisiensi hasil fotosintesis.

Peningkatkan populasi tanaman dengan memperbanyak lubang tanam dengan penanaman tanaman satu tanaman per lubang akan memberikan hasil panaen yang baik. Peningkatan populasi dengan meperbanyak jumlah tanaman pada lubang tanam dapat membuat pesaingan akar tanaman dalam memperoleh air dan unsur hara. Penelitian Made (2010) menunjukkan bahwa penanaman 3 tanaman per rumpun jagung manis menghasilkan tongkol yang kecil dan pendek, serta jumlah berat tongkol berkurang karena populasi tanaman tiap rumpun yang banyak menyebabkan persaingan dalam satu rumpun. Tumpang tindihnya sistem perakaran dan semakin meningkatknya frekuensi akar dalam satu rumpun mempengaruhi tingat absorbsi air dan hara disekitar tanaman menyebabkan terjadinya kompetisisuplai faktor tumbuh.

Indeks panen jagung manis tidak secara nyata dipengaruhi oleh perlakuan tanam lingkar berjajar (tabel 6.). Indeks panen jagung manis antar perlakuan tanam lingkar berjajar tidak berbeda nyata. Indeks panen tanaman jagung manis paling tinggi diperoleh perlakuan tanam tunggal dengan jarak tanam 20x60 cm yaitu 0,54 dan paling rendah diperoleh perlakuan tanam lingkar berjajar dengan jarak tanam 60x80 $\mathrm{cm}$ yaitu 0,48. Hasil panen tanaman budidaya dapat ditingkatkan dengan cara meningkatkan berat kering total yang dihasilkan dan atau meningkatkan proporsi hasil panen ekonomis. Pada tanaman berbiji, peningkatan hasil panen biji disebabkan oleh peningkatan indeks panen. Pada masa generatif tanaman tidak lagi memproduksi berat kering total tanaman tetapi 
lebih banyak membagiberat keringnya ke hasil panen biji. (Gardner dkk. 1991). Semakin banyak berat kering ayng teralokasikan pada hasil panen eokonomis maka tanaman budidaya semakin ekonomis.

\section{KESIMPULAN}

Kesimpulan yang dapat disampaikan berdasarkan hasil penelitian sebagai berikut :

1. Perlakuan tanam lingkar berjajar meningkatkan populasi tanaman jagung manis sebesar 239 - $274 \%$ dari tanam tunggal.

2. Tanam Lingkar berjajar dengan jarak tanam 70x80 $\mathrm{cm}$ dengan jumlah populasi 75.382 per Ha menghasilkan berat tongkol segar sebesar 26,06 ton/Ha.

\section{DAFTAR PUSTAKA}

Andarias, 2008. Teknologi Budidaya Jagung.Badan Litbang Pertanian.

Anonymous. 2017. Bonanza 2 F1. PT East West Seed Indinesia. http: www. Panahmerah.id. 14 Juni 2017.

Ditjend tanaman pangan, 2016. Petunjuk Teknis gerakan pengembangan jagung hibrida. Kementrian pertanian.

Etica, Use dan M. Hamawi. 2016. Pengaruh Metode Tanam Lingkar Berjajar dan Varietas Jagung Hibrida Terhadap Produksi Jagung (Zea mays L.). Gontor Agrotech Science Journal. Vol 2. No. 2, Juni 2016. Halaman 71 91.

Evy Thyrida, Edison dan Jasmani, 2013. Pertumbuhan Dan Produksi Jagung Manis Pada Berbagai Jarak Tanam Dan Waktu Olah Tanah. Jurnal Online Agroteknologi Vol.1, No.3, Junu 2013.

Gardner, F.B; R.B. Pearch; R.L. Mitchell. 1991. Fisiologi Tanaman Budidaya. Universitas Indonesia. Halaman 147-161.

Koswara, J. 1986. Budidaya Jagung Manis. Yasaguna. Jakarta.

Larosa O. L, dan Simanungkalit, T. 2014. Pertumbuhan dan Produksi Jagung Manis (Zea mays saccharata Sturt.) pada Beberapa Persiapan Tanah dan Jarak Tanam. Jurnal Agroteknologi. ISSN No. 2337 - 6597. Vol 3, No. 1 : 01-07 Desember 2014. 
Made, Usman. 2010. Respon Berbagai Populasi Tanaman Jagung Manis (Zea mays saccharata Sturt.) Terhadap Pemberian Pupuk Urea. Journal Agroland 17 (2) : 138 - 143, Agustus 2010.

Rambitan, V.M.M. 2004. Pertumbuhan dan Hasil Empat Kultivar Jagung Semi (Baby Corn) dengan Berbagai Populasi Tanaman Pada Inceptisols Jatinangor. J. Agroland Vol. 11(1) : 11-17.

Sudiana, I. M., dan Eka Martiningsih. 2012. Penerapan Teknologi Jarak Tanam dan Varietas Jagung Hibrida Berbasis Semi Organik. Majalah Aplikasi Ipteks Ngayah. 3(4), 2012.33-43.

Syukur dan Aziz rifianto, 2014. Jagung Manis. Penebar swadaya

Sutardjo, Sulastri dan Winda. 2012. Optimasi Produksi Empat Varietas Jagung Hibrida di Kertosono Kabupaten Nganjuk. Jurnal Sains dan Teknologi Indonesia Vol. 14, No. 1, April 2012 halaman 76-80.

Syafri dan Eva Salvia, Inovasi Teknologi Budidaya Dalam Rangka Pengembangan Usahatani Jagung di Provinsi Jambi, (Prosiding Pekan Serealia Nasional, (Balai Pengkajian Teknologi Pertanian Jambi, 2011.ISBN: 978 979-8940-29-3).

Subekti. 2008. Morfologi tanaman dan fase pertumbuhan jagung. Balai penelitian tanaman serealia. Maros. p. 16-28

Usman Made, Respon Beberapa Populasi Tanaman Jagung Manis Terhadap Pemberian Pupuk Urea, (Jurnal Agroland 17 (2):138-143, Agustus 2010. ISSN:0854-642X).

Williams, Mc. 1999. Corn Growth and Management Quick Guide. www.ag.ndsu.edu. (Verified 28 September 2008). 